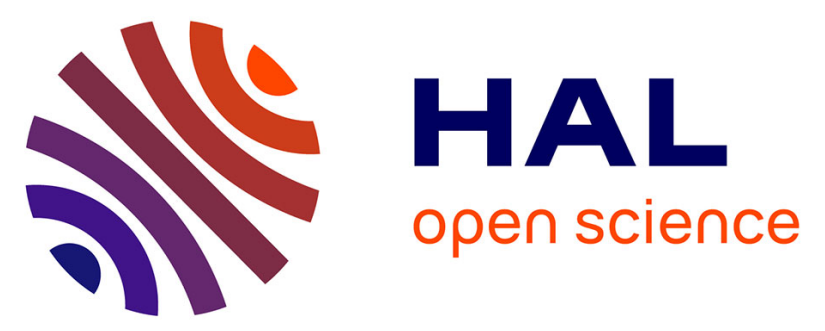

\title{
Effect of diet on the biochemical composition of Paracentrotus lividus (Echinodermata: Echinoidea) under natural and rearing conditions (effect of diet on biochemical composition of urchins)
}

Catherine Fernandez

\section{To cite this version:}

Catherine Fernandez. Effect of diet on the biochemical composition of Paracentrotus lividus (Echinodermata: Echinoidea) under natural and rearing conditions (effect of diet on biochemical composition of urchins). Comparative Biochemistry and Physiology - A: Comparative Physiology, 1997, 118 (4), pp.1377 - 1384. 10.1016/S0300-9629(97)00221-1 . hal-01768447

\section{HAL Id: hal-01768447 \\ https://hal.science/hal-01768447}

Submitted on 17 Apr 2018

HAL is a multi-disciplinary open access archive for the deposit and dissemination of scientific research documents, whether they are published or not. The documents may come from teaching and research institutions in France or abroad, or from public or private research centers.
L'archive ouverte pluridisciplinaire HAL, est destinée au dépôt et à la diffusion de documents scientifiques de niveau recherche, publiés ou non, émanant des établissements d'enseignement et de recherche français ou étrangers, des laboratoires publics ou privés. 


\title{
Effect of Diet on the Biochemical Composition of Paracentrotus lividus (Echinodermata: Echinoidea) Under Natural and Rearing Conditions (Effect of Diet on Biochemical Composition of Urchins)
}

\author{
Catherine Fernandez \\ CEVAREN, Université de Corse, B.P. 52; 20250 Corte, France
}

\begin{abstract}
The hiochemical composition (expressed as \% dry weight) of the test, gut and gonad of Paracentrotus lividus was estimated. Sea urchin biochemical composition was studied in two natural populations of a coastal Mediterranean lagoon and in two rearing stations, one in open sea and one inland. Artificials feeds were administered to the reared urchins in order to evaluate variations in the biochemical composition of this species when provided different food resources. The results reveal that, for the natural populations examined in this study, the biochemical composition of the gonad, gut, and test do not depend on food availability and, hence on the yuantity of food consumed. The comparison between wild and reared sea urchin hiochemistry reveals that organ hiochemical composition is strongly influenced by the quality of the feed. The use of artificial teed cuntaining fish meal (rich in protein), favours a storage of reserves in the gonad, the gut, and even in the test in the form of lipids and/or carbohydrates. This is true for both open sea and inland rearing.
\end{abstract}

KEY WORDS. Aquaculture, artificial diet, biochemical composition, inland and open sea rearing, lagoonal environment, Paracentrotus lividus, sea urchin

\section{INTRODUCTION}

The biochemical composition of sea urchin organs has been studied in several species originating from various environments including shallow, deep, tropical, temperate and polar waters $(11,21,29,30,31)$. Several authors have also studied the biochemical evolution of sea urchins during starvation $(4,5)$ in order to increase our understanding of storage in the different organs of the Echinoidea. Despite these studies, little information is available on the effect of diet on tissue hiochemical composition.

Paracentrotus lividus (Lamarck) is a very widespread species on Atlantic and Mediterranean coasts, and plays an important role in the development of benthic macrophyte (36). This species is also subject to intensive commercial fishing in several countries. For this reason, a considerable number of studies have been undertaken dealing with sea urchin nutrition and growth in order to improve the farming of this species $(10,14,25,26)$. There has been little research carried out, however, which focuses on urchin hiochemical composition.

The aim of this study was, therefore, to monitor the effect

Address reprint requests to: Catherine Fernandez. CEVAREN, Université de Corse, R.P. 52; 20250 Corte. France. Tel. 0495-450075; Fax 0495. 462441: E-mail: cyel@

Received 7 January 1997; revised 8 April 1997; accepted 24 April 1997. of diet on sea urchin hiochemical composition in populations living in the field (populations with or without access to an abundant food source) and in rearing sites (individuals fed in excess with different artificial or natural feeds). This information should allow for a better understanding of the nutrition of sea urchin, particularly how feeds affect the biochemical composition of the body components and therefore how nutrients are allocated to the different tissues. The results should help to define an adapted artificial diet which is important for the successful development of sea urchin farming.

\section{MATERIALS AND METHODS}

To observe the effect of diec on the hiochemical composition of sea urchins, individuals sampled from different populations were analyzed. Four populations were examined in all. Two are natural populations whose food resources are either low or abundant. The other two are reared populations, one present in the lagoon (open sea semi-extensive rearing) and the other in the large tank of a pilot sea farm (intensive inland rearing). Reared populations were fed natural and artificial feeds.

In situ, specimens of Paracentrotus lividus were collected from two sites situated in the Urbinu lagoon. This lagoon is located on the eastern coast of Cirsica (Mediterranean. 
France) ( $4203^{\prime} \mathrm{N} ; 928^{\prime} \mathrm{E}$ ). These two stations differ mainly in the availability of food. Other conditions (depth, hydrodynamism, temperature and salinity) are similar at both stations. The "pebble station" consists of a bottom made up of pebbles and is very sparsely occupied by macrophytes. Sea urchins at this station consume mostly plant detritus, dead animals and micro-phytobenthos (7). The "seagrass bed station" is characterized by a sandy bottom colonized by Cymodocea nodosa (Ucria) Asherson (seagrass) and provides an abundant supply of food. Indeed, Cymodocea nodosa is considered to be a preferential food source of Paracentrotus lividus (34). The repletion index is always lower for individuals from the pebble station (where trophic resources are limiting) than for those from the seagrass bed station. These differences of nutrition between the two stations more distinct than the repletion index would seem to suggest, if the level of organic matter really ingested is examined. At the pebble station, approximately $53 \%$ of the gut content consists of mineral material not used by sea urchins; the plant fraction accounts for only $24 \%$ of the content. At the seagrass bed station, the mineral fraction is only $3 \%$, while plant matter represents $95 \%$ of the gut content (7). Samples were taken from both stations and from two size classes. Ten sea urchins 31-40 mm and another ten $41-50 \mathrm{~mm}$ in diameter were sampled quarterly (August 1991, November 1991; February 1992 and May 1992). The data obtained from the last samples will be used as a reference in the comparison with reared sea urchin data. As a result, only the samples month and size classes which correspond exactly to those performed for reared specimens will be presented here.

For the "open sea rearing in enclosure" station, sea urchins were grown for 2 years in four enclosures set up in the Urbinu lagoon. The enclosures consisted of rectangular net pens $(2 \mathrm{~m} \times 1 \mathrm{~m})$. The sides and the bottom were made of $1 \mathrm{~cm}$ mesh plastic netting. The enclosures were positioned in such a way that the netting was at least $20 \mathrm{~cm}$ above the surface of the water at high tide, and the bottom was $30 \mathrm{~cm}$ above the substrate (8). Diet during the rearing period consisted of one of the following four different feed types and was supplied once or twice weekly. In enclosure 1 , the feed provided was the marine phanerogam Cymodocea nodosa. In enclosure 2, a vegetable-based artificial feed (rich in carbohydrates) was distributed. In enclosure 3, the feed type consisted of a mixed-based artificial feed (balanced between proteins and carbohydrates) and, in enclosure 4, the feed distributed consisted of an animal-based artificial feed (rich in proteins). A more in depth description of the feeds composition is provided in Table 1. Ten sea urchins (size class $31-40 \mathrm{~mm}$ ) were sampled quarterly from each enclosure from November 1992 to May 1993.

For the "intensive in land rearing in tank," sea urchins were grown for 6 month in tanks of an urchin pilot farm scheme. This experimental set-up consists of a building measuring $9 \mathrm{~m}$ by $4 \mathrm{~m}$ housing several series of superimposed tanks $(3 \mathrm{~m} \times 0.15 \mathrm{~m} \times 0.15 \mathrm{~m})$ that are used for rearing operations. For each series, the water circulates through the force of gravity between the tanks. The cascades resulting from this arrangement enable the water to be oxygenated. The experiments were carried out in four of these tanks. The farming facility's water flows through an open circuit to the lagoon. The water temperature does not differ from the lagoon temperature, and follows the seasonal variations (from $8^{\circ} \mathrm{C}$ in February to $30^{\circ} \mathrm{C}$ in August) (8). Diet during the rearing period consisted of the four different feed types mentioned above: in tank 1 , the feed provided was the marine phanerogam Cymodocea nodosa; in tank 2, the vegetable-based artificial feed, in tank 3 , the mixed-based artificial feed and in tank 4, the animal-based artificial feed. Ten sea urchins (size class $41-50 \mathrm{~mm}$ ) were sampled from each rearing tank at the end of the experimental period (August 1994).

All individuals were dissected into their various body components: the test (with spines), the gonad, and the gut. Half of the tissues was homogenized with an Ultra turax and the level of soluble proteins, carbohydrates and lipids was estimated using the Lowry method (27), Dubois method. (4) and Barnes and Blacktock method (1) techniques, respectively. Water content was determined by placing the remaining half part of the tissues in an oven at $70^{\circ} \mathrm{C}$ until a constant weight was obtained. Ash content was determined by placing the dried tissues in a muffle furnace at $500^{\circ} \mathrm{C}$ for $4 \mathrm{hr}$. Insoluble protein levels were estimated by subtraction as described by Lawrence and Kafri (22) (Although this method is a generally accepted method, it may be a little problematic with mature testes for which nucleic acids may contribute significantly to the composition of the tissue, rather than insoluble proteins).

Data were processed by one-way-analysis of variance (ANOVA) in order to enable the monthly comparison for each biochemical component of gonad, gut and test. These Anova were followed by Tukey tests (36). Beforehand, normality and homoscedasticity were verified by Kolmogorov. Smirnov and Bartlett tests, respectively (36). To observed the effect of site/diet on seasonal variations, two-way $\Lambda N O V \Lambda$ were used. The two factors analyzed were the "site/diet" factor and the "season" factor. These analysis were performed only for the sea urchins collected in situ and in enclosures (size class $31-40 \mathrm{~mm}$ ) for each tissue and each biochemical component. The software Statgraphics plus (v. 1.4) for Windows was used.

\section{RESULTS}

The biochemical composition of sea urchin tissues sampled from the natural populations and rearing stations are given in Figs $l$ to 3.

Results of the statistical analysis reveal that the biochemical composition of the gonads in sea urchins sampled from the two in situ sites (pebble area and seagrass beds) is similar for all the components examined and this regardless of sam- 
TABLE 1. Ingredients used in the preparation of the artificial feed (expressed as a percentage). The artificial feed contain $56 \%$ of base meal mixed into a $12.5 \%$ gelatin solution. Biochemical composition is also expressed as a percentage (in dry weight). Energetic levels are expressed in $\mathbf{k J} \cdot \mathrm{g}^{-1} \mathrm{dry}$ weight

\begin{tabular}{|c|c|c|c|}
\hline & $\begin{array}{l}\text { Vegetable-based } \\
\text { artificial feed }\end{array}$ & $\begin{array}{l}\text { Mixed-based } \\
\text { artificial feed }\end{array}$ & $\begin{array}{l}\text { Animal-based } \\
\text { artificial feed }\end{array}$ \\
\hline Corn meal & $44.7 \%$ & $22.35 \%$ & $0.0 \%$ \\
\hline Fish meal & $0.0 \%$ & $44.70 \%$ & $89.4 \%$ \\
\hline Sunflower oil & $8.9 \%$ & $4.45 \%$ & $0.0 \%$ \\
\hline Cod liver oil & $0.0 \%$ & $4.45 \%$ & $8.9 \%$ \\
\hline $\begin{array}{l}\text { Vitamin and mineral } \\
\text { mixture }\end{array}$ & $1.7 \%$ & $1.70 \%$ & $1.7 \%$ \\
\hline Soluble proteins & $12.7 \%$ & $28.9 \%$ & $47.2 \%$ \\
\hline Soluble carhohydrates & $58.2 \%$ & $35.3 \%$ & $15.9 \%$ \\
\hline Total lipids & $10.7 \%$ & $12.8 \%$ & $15.5 \%$ \\
\hline Ash & $4.9 \%$ & $8.1 \%$ & $10.7 \%$ \\
\hline
\end{tabular}

"The mixture is made up of (expressed in $\mathrm{mg}$ or UI/kg of feed): Tocopherol acetate: $70.8 \mathrm{UI}$, ascorhic acid: $283 \mathrm{mg}$; Thiamin: $7.1 \mathrm{mg}$; Rihoflavin: $7.6 \mathrm{mg}$; Pyridoxine: $9.4 \mathrm{mg}$; cyanobalanine: $0.014 \mathrm{mg}$; Biotine: $0.47 \mathrm{mg}$; Folic acid: $1.89 \mathrm{mg}$; calcium pantothenate: $23.6 \mathrm{mg}$; Vit A: $710 \mathrm{UI}$; vit $\mathrm{D}_{3}: 700 \mathrm{UI}$; Niacin: $14.6 \mathrm{mg} ; \mathrm{CaCO}_{4}: 2.1 \mathrm{mg} ; \mathrm{Cu} \mathrm{SO}_{4}: 9.4 ; \mathrm{Fe} \mathrm{SO}_{4}: 4.7 \mathrm{mg} ; \mathrm{NaF}: 7.1 \mathrm{mg} ; \mathrm{Mg} \mathrm{CO}_{4}: 174 \mathrm{mg} ; \mathrm{Mn} \mathrm{SO}$ : $18.9 \mathrm{mg} ; \mathrm{CaHPO}_{4}: 75.5 \mathrm{mg}: \mathrm{Zn} \mathrm{SO}: 7.7 \mathrm{mg}$.

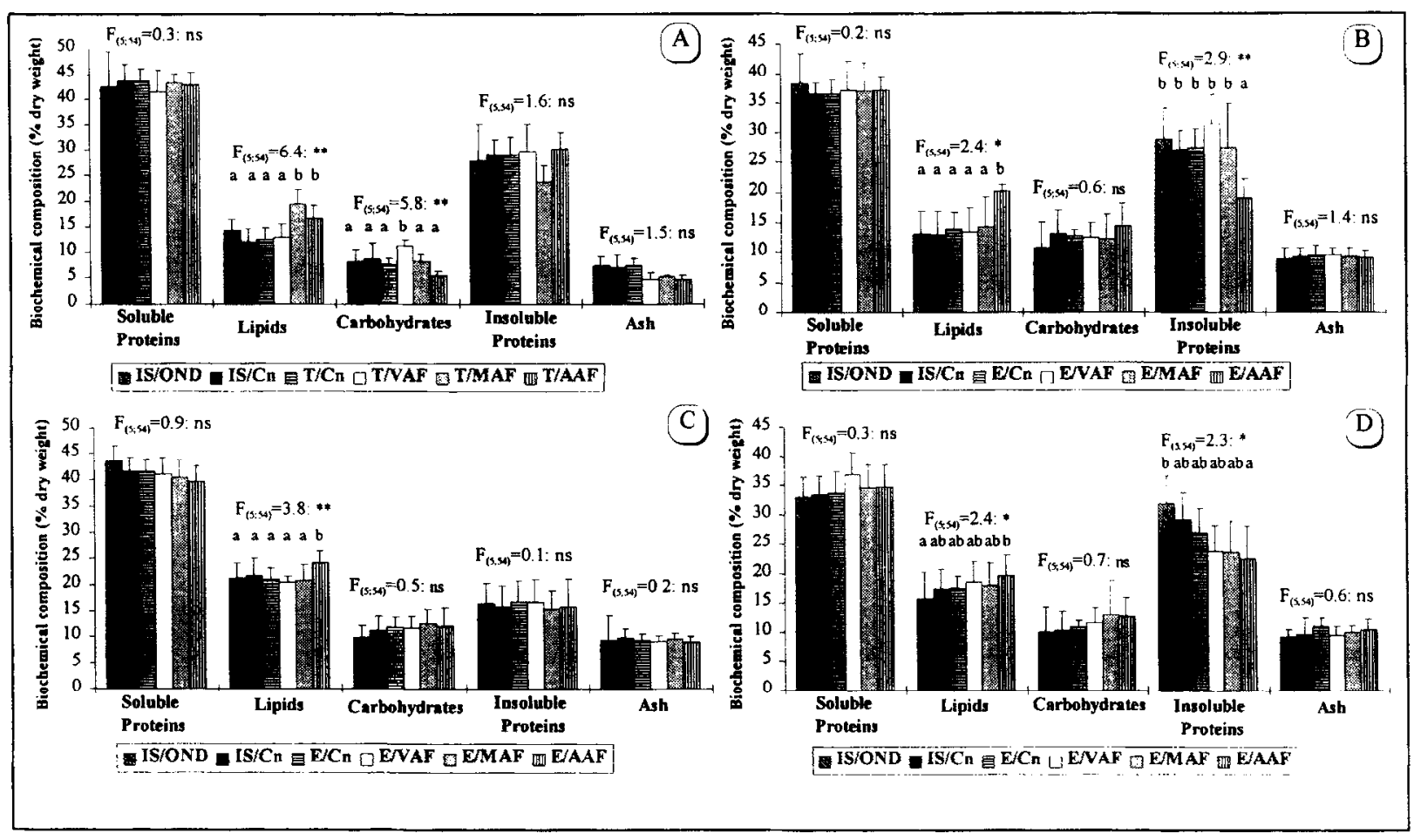

FIG. 1. Paracentrotus lividus. Biochemical composition of the gonads ( $m e a n+C I$ ) for the 4 samplins months (A to D) and for the 6 sea urchin groups. Populations: IS: in situ population; T: intensive rearing in Tanks, E: open sea rearing in Enclosures. Diets: NOD: natural omnivore diet, Cn: Cymodocea nodosa, VAF: vegetable-based artificial feed, MAF: mixed-based artificial feed, AAF: animal-based artificial feed. A: in August, size class 41-50 mm; B: in November, size class 31-40 mm; C: in February, size class 31-40 mm; D: in May, size class 31-40 mm. Note. Also shown are the ANOVA test results: degrees of freedom, $F$ values, significance level (ns: nonsignificant, ${ }^{*} p>0.05 ;{ }^{* *} p>0.01$ ). Tukey test is presented when ANOVA is significant: values that do not differ at the 0.05 level are noted with the same letter. 


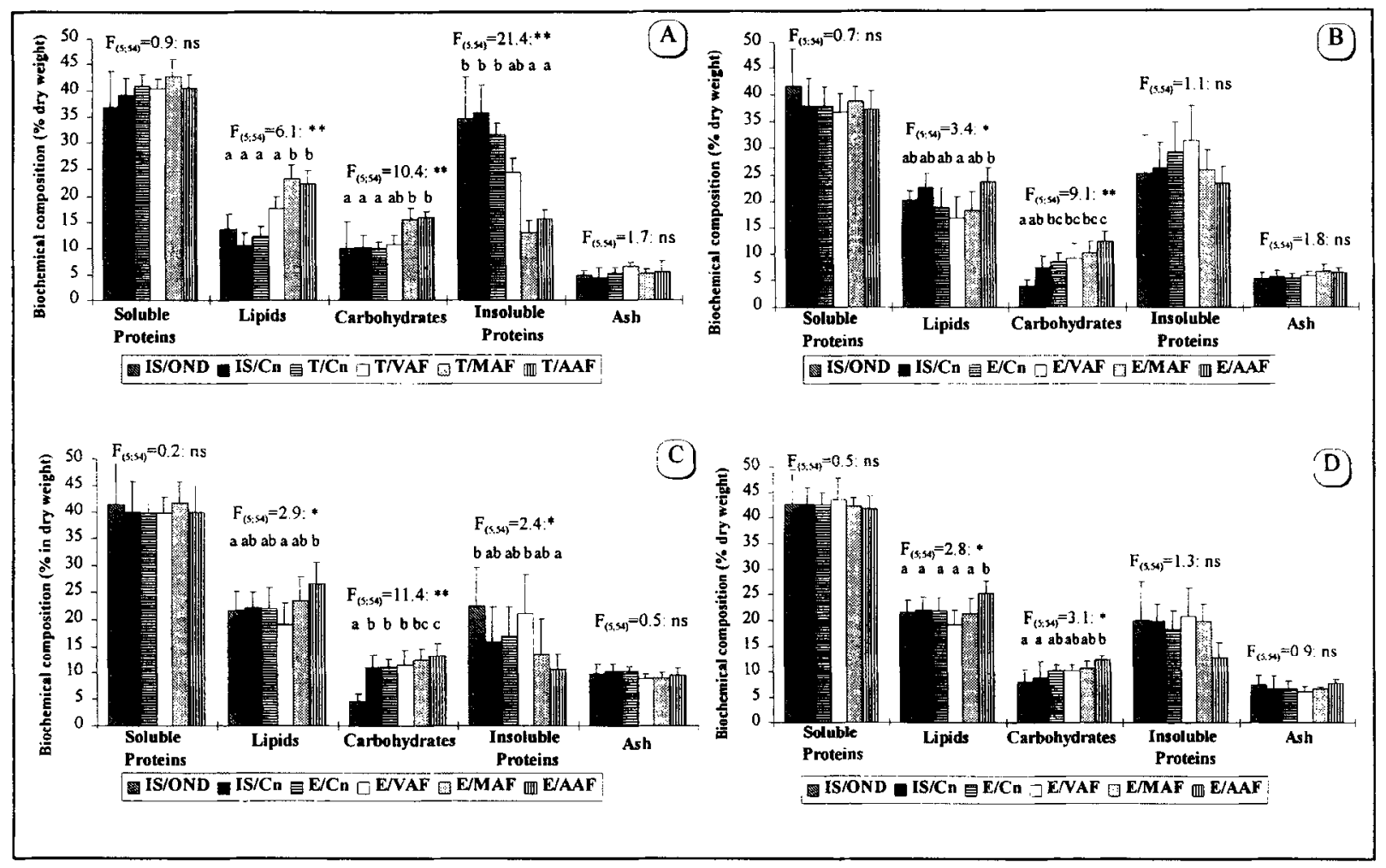

FIG. 2. Paracentrotus lividus. Biochemical composition of the gut (mean $+\mathrm{CI}$ ) for the 4 sampling months (A to D) and for the six sea urchin groups. Populations: IS: in situ population; T: intensive rearing in Tanks, E: open sea rearing in Enclosures. Diets: NOD: natural omnivore diet, Cn: Cymodocea nodosa, VAF: vegetable-based artificial feed, MAF: mixed-based artificial feed, AAF: Animal-based artificial feed. A: in August, size class $41-50 \mathrm{~mm}$; B: in November, size class $31-40 \mathrm{~mm}$; : in February, size class 31-40 mm; D: in May, size class 31-40 mm. Note. Also shown are the ANOVA test results: degrees of freedom, $F$ values, significance level (ns: nonsignificant, ${ }^{*} p>0.05 ;{ }^{* *} p>0.01$ ). Tukey test is presented when ANOVA is significant: values that do not differ at the 0.05 level are noted with the same letter.

pling month (cf. ANOVA tests results in Fig. 1, for all of them, $P>0.05$ ) (i.e., approximate biochemical composition of the gonads in August: soluble proteins $43 \%$, insoluble proteins $29 \%$, carbohydrates $8 \%$, lipids $13 \%$ and ash $7 \%)$. In situ, the biochemical composition of the test is also similar (for all the components) at both of the studied sites and this for the four sampling month ( $c f$. NNOVA tests results in Fig. 3, for all of them, $P>0.05$ ) (i.e., approximate biochemical composition of the tests in August: soluble proteins $3 \%$, insoluble proteins $14 \%$, carbohydrates $0.2 \%$, lipids $0.3 \%$, and ash $82.5 \%$ ). For the gut, the only significant difference observed between the two sites is for the carbohydrates levels in February (ANOVA test, $F(5,54)=11.4$, $P<0.05$ ): the carbohydrate level is greater in the gut of urchins living on the seagrass bed than is observed for those living on the pebble bottom. No significant differences are observed for the remaining biochemical components month (cf. ANOVA tests results in Fig. 2, P>0.05) (i.e., approximate biochemical composition of the gut in August: soluble proteins $37 \%$, insoluble proteins $35 \%$, carbohydrates $10 \%$, lipids $12 \%$ and ash $4 \%$ ).
The reared sea urchins exhibit significant variations in their biochemical composition depending on the type of feed provided and this for the gonad (Fig. 1), gut (Fig. 2), and test (Fig. 3).

For the gonads, lipid levels are higher when individuals are fed either the animal-based feed (i.e. 20\% in November) and occasionally with mixed-based feed than with others feeds (i.e., $13 \%$ in November with Cymodocea nodosa) (cf. ANOVA test results, Fig. 1). Differences are also observed for carbohydrates but only for sea urchins reared in tanks: gonad carbohydrate levels are highest when sea urchins are fed the vegetahle-based artificial feed while the gonad lipid levels are highest when individuals are fed the animal and mixed artificial feeds (cf. ANOVA test results, Fig. 1). A comparison between the natural population and the reared sea urchin data reveals that reared individuals fed Cymodocea nodosa have the same gonad biochemical composition as those of the natural population and this regardless of the rearing conditions (open-sea or inland) (cf. Tukey test results, Fig. 1). For the other biochemical components, soluble proteins and ash do not vary according to diet (cf. 


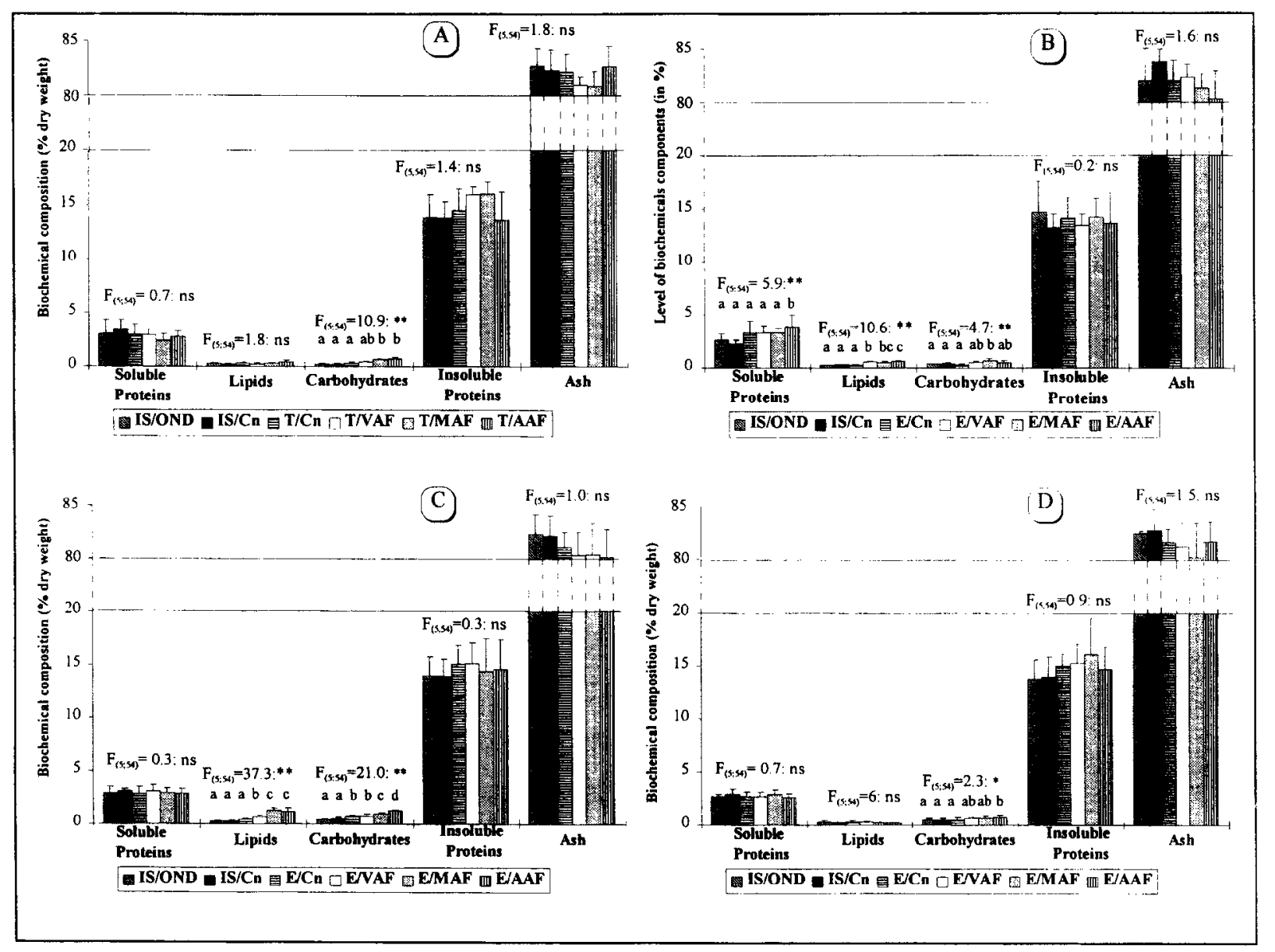

FIG. 3. Paracentrotus lividus. Biochemical composition of the test (mean + CI) for the 4 samplins months (A to D) and for the 6 sea urchin groups. Populations: IS: in situ population; T: intensive rearing in Tanks, E: open sea rearing in Enclosures. Diets: NOD: natural omnivore diet, Cn: Cymodocea nodosa, VAF: vegetable-based artificial feed, MAF: mixed-based artificial feed, AAF: Animal-based artificial feed. A: in August, size class 41-50 mm; B: in November, size class $31-40 \mathrm{~mm}$; C: in February, size class 31-40 mm; D: in May, size class 31-40 mm. Note. Also shown are the ANOVA test results: degrees of freedom, $F$ values, significance level (ns: nonsignificant, ${ }^{*} p>0.05 ;{ }^{* *} p>0.01$ ). Tukey test is presented when ANOVA is significant: values that do not differ at the 0.05 level are noted with the same letter.

ANOVA test results, Fig. 2). The variations observed in insoluble protein levels are only a reflection of the lipid or carbohydrate differences.

For the gut, the influence of diet on gut carbohydrate, lipid levels and insoluble protein levels is significant ( $c f$. ANOVA test results, Fig. 2). Globally, the lipids and carbohydrate levels are higher in sea urchins fed mixed and animal artificial feeds (in rearing in tanks, or in enclosures) than with the other feeds (i.e. in tanks in august, $23.3 \%$ of lipids, $15.7 \%$ of carbohydrates with mixed diet and $12.4 \%$ of lipids, $10.1 \%$ of carbohydrates with Cymodocea nodosa) (Tukey test, Fig. 2). As was observed for the gonad, the gut biochemical composition in the natural sea urchin population is similar (in soluble proteins, lipids, carbohydrates, insoluble proteins and ash) to that observed in reared individuals fed Cymodocea nodosa (cf. Tukey test results, Fig. 2).
For the test, the diet of reared sea urchins seems to influence the carbohydrate and/or lipid levels (cf. ANOVA test results, Fig. 3). Generally, the lowest levels are observed in individuals fed Cymodocea nodosa (i.e., $0.4 \%$ of lipids and $0.7 \%$ carbohydrates in enclosures, in Fehruary), and the highest levels are recorded for animals fed the mixed feed or animal feed (i.e, with animal feeds: $1.2 \%$ of lipids and $1.3 \%$ carbohydrates in enclosures, in February) (Tukey test, Fig. 2). As was observed for the two other tissues, individuals form the natural populations have the same test biochemical composition (soluble proteins, lipids, carbohydrates, insoluble proteins and ash) as that observed in reared individuals fed Cymodocea nodosa (Tukey test, Fig. 2).

Statistical analysis of the seasonal variations of the different biochemical components reveals that these variations are mainly significant for the gonads and gut. For the go- 
nads, seasonal variations are observed mostly for the proteins (two-way ANOVA, season factor, $F=32.3, P<$ 0.001 ), lipids (two-way ANOVA, season factor, $F=32.8$, $P<0.001$ ) and in soluble (two-way ANOVA, season factor, $F=40.7, P<0.001$ ). Statistical analysis reveals that the interaction between the two factors (diet/site and season) are not significant (two-way ANOVA, interaction, $F$ $=0.19$ to $1.1, P>0.05$ ). This would seem to suggest that the seasonal variations observed are identical regardless to the habitat (in situ or in rearing) or the food ingested by the sea urchin (natural food or artificial food). For the gut, seasonal variations are observed for the proteins (two-way Anova, season factor, $F=5.8, P<0.01$ ), lipids (two-way ANOVA, season factor, $F=6.4, P<0.05$ ), carbohydrates (two-way ANOVA, season factor, $F=7.8, P<0.001$ ) and insoluble proteins levels (two-way ANOVA, interactions, $F=31.3, P<0.001$ ). As above, statistical analysis reveals that the interaction between the two factors (site/diet and season) are not significant, (two-way ANOVA, intersection, $F=0.17$ to $3.36, P>0.05$ ). As for gonads seasonal variations observed on biochemical component of the gut are similar whatever the site and the food provided.

\section{DISCUSSION}

The results of the present study reveal that, the biochemical composition of Paracentrotus lividus is similar to that observed in urchins from other parts of the world $(6,7,11$, $12,16,17,18,-31,33)$. The gonads and gut contain a high level of protein both soluble and insoluble). Lipids are also relatively abundant while carbohydrate levels are low. This distribution is almost identical to that observed in a large number of Echinoidea from Antarctic, temperate and tropical waters $(11,12,20,21,30)$. Such similarities in the distribution of biochemical components are due to the organization of the various organs which is similar in all the Echinoidea, and this regardless of species and geographical location $(21,30)$. As was found for the other organs examined, no major difference in the composition of the test is observed between sea urchins of the present study and those living at different latitudes or depths $(21,30)$. The majority of the test is always composed of ash originating from the skeletal matter. The most abundant organic compounds are the soluble and insoluble proteins while the lipid and carbohydrate levels are low. The importance level of skeletal material in the test points to the structural function of this organ (30).

If the biochemical composition is quite similar in all parts of the world, our results show that this composition can be influenced, under rearing conditions, by the food provided. In the presented study, the fond available to the two natural populations, however, did not seem to influence the biochemical composition of the various tissue components examined. Due to the greater availability of food in the seagrass bed, it was conceivable that individuals living in this habitat beds would have contained more lipids and carbohydrates, and this in all three of the tissues examined. Indeed, the stocking of reserves in different organs is well documented in sea urchins $(6,7,15,17,18,24)$ and studics on the utilization of reserves during starvation show that lipids and carbohydrates in the gonad, gut and test are solicited $(6,24)$. Other studies have shown that the availability of food affects the degree of development of the reserve in gonad (23) and, therefore, biochemical composition. Our data indicate, however, that no noticeable imbalance in the biochemical composition exists and this despite the evident difference in food availability between the two populations. Sea urchins living on the seagrass beds do not exhibit overly important lipid and carbohydrate levels while those living on pebble bottoms do not present a deficiency in these components. The quantity of food consumed by sea urchins living on pebble bottoms seems to be sufficient to support at least maintenance and reproduction. Nevertheless, it is necessary to note that the total energy stocked in the various tissue types is always greater for individuals living on Cymodocea nodosa beds as compared to those living on pebbles bottom. This is due to the fact that individuals living on seagrass beds possess a relative gonad and test weight that is greater than that observed in individuals living on pebble bottoms (8). Energy reserves are therefore very different at the two sites. As Fenaux et al. (6) observed that cellular destruction in the gonad was sufficient to cover immediate energy needs and this without changing the biochemical composition, we can say that sea urchins from seagrass beds therefore possess important levels of reserves within the gonad regardless of the period of the year.

Conversely, rearing in enclosures or tanks using an artificial diet has a noticeable effect on the biochemical composition of the tissues. For the gonad, this effect is primarily observed on the carbohydrate and/or lipid levels. Sea urchins fed a diet composed of fish meal present gonads rich in lipids. These results differ from those of De Jong-Westman et al. (3) for Strongylocentrotus droebachiensis. Echinoidea gonads are important reserve tissues $(5,6,11,12,15$, $17,18)$. This storage occurs in one of two ways; either through an increase in the size of the gonad or through the storage of nutrients (lipids or carbohydrates) within specialized cells (13). It has previously been shown that rearing using artificial feeds brings about an important gonadal weight increase in Paracentrotus lividus (10). This increase seems to be due, at least in part, to an accumulation of lipid and/or carbohydrate reserves in the cells of this organ. Conversely, in natural populations, an abundance of food causes an increase in gonad weight (8) without varying the biochemical composition. Comparison between the two rearing methods seems to reveal that the biochemical composition of the gonad is less influenced when urchins are reared in enclosures (only lipids change). This could be due to the fact that individuals reared in parks can ingest, in addition to the artificial diet provided, the fouling products gener- 
ated within the enclosures as well as floating vegetable matter. As a result, these additional food sources will attenuate the differences in the initial diets provided and, therefore, limit the effect of diet on gonad biochemical composition. Nevertheless, the same tendency toward an increase in lipids levels was observed for individuals fed the animal or vegetable feeds. As in the gonad, the gut, particularly the stomach, may serve as a nutrient storage organ (2). This organ allows the immediate storage of excess nutrients (23). Reserves are in the form of lipids and carhohydrates $(2,24)$ and are immediately solicited under food limiting conditions (6). Biochemical composition data for the gut of reared sea urchins fed the two protein-rich feeds reveal that these feeds allow not only important growth of this organ (8), but also lead to an accumulation of reserves within the gut. For the test as well, rearing using artificial feed composed of fish meal allows the stocking of reserves in the form of carbohydrates and lipids. Several authors have demonstrated the role that this organ plays in the stocking of reserves $(6,19)$. Under food limiting conditions, carbohydrates of the test are used first, followed by the lipids and proteins $(6,19)$.

Seasonal variations in the biochemical composition of the gonads and gut have already observed of other species $(5,28,32,33)$. As a general rule, these variations are linked to the reproductive cycle for the gonads $(5,33)$ and to the season feeding level (repletion index cycle) and/or reproductive cycle for the gut $(5,23)$. The results obtained here, although limited, seem to be in agreement with those obtained by other authors: an accumulation of reserves is seen in the gonads during gonadal growth period (high levels in February) and an increase in proteins levels during gametogenesis (in May). It is important to note that the biochemical composition variations in wild sea urchins are identical to those observer for reared urchins. This would seem to suggest that, despite an accumulation of reserves, the physiological (reproduction) and feeding cycles are not affected by rearing conditions and do not appear to be influenced by the type of food ingested.

A number of studies dealing with Paracentrotus lividus aquaculture indicate that the quality of the artificial feed used for rearing influences a number of parameters which include test growth $(8,9)$, gonadic growth $(10)$ and nutrition parameters (8). This study seems to demonstrate that the quality of the food also greatly influence the biochemical composition of the sea urchin body components. The above studies reveals that protein-rich feed (animal-based artificial feed and mixed-based artificial feed) allow an important somatic and gonadic growth from a low levels of feeding $(8,10)$ but also lead to the storage of nutrients in the different sea urchin organs particularly in gonads. The lipid and carbohydrate reserves are generally considerate to be lost energy (mainly for growth) by sea farmers and can, in addition, alter the gustatory quality of the products. It would, therefore, appear to be of prime importance to improve the feed composition in order to obtain the fastest growth possible while at the same time limiting excessive nutrient storage (especially in the test and the gut). For the gonad, however, this accumulation of reserves is a beneficial aspect for it contributes to the development of this organ, which is economically interesting for the roe market.

The author wishes to thank C.F. Boudouresque and J.M. Lawrence for their comments on the earlier draft of this manuscript and the three anonymous referees for valuable criticism I also thank L. Bronzini of Caraffa, manager of the SCORSA for allowing me to work in the Urbinu lagoon and for making available facilities at sea. I would also like to thank Prof. D. Viale, of the Universite de Corse, for the interest that she has shoun in my research.

\section{References}

1. Barnes, H,; Blackstock, J. Estimation of lipids in animal tissues: Detailed investigation of sulfovanillin methods for total lipids. J. Expl. Mar. Biol. Ecol. 12:103-113;1973.

2. Bishop, C.D.; Watts, S.A. Biochemical and morphometric study of growth in the stomach and intestine of the echinoid Lytechinus variegatus (Echinodermata). Mar. Bisl. I 14:459 $467 ; 1992$.

3. De Jong-Westman, M.; March, B.E; Carefoot, T.H. The effect of different nutrient formulation in artificial diets on gonad growth in the sea urchin Strongylocentrotus droebachiensis. Can. J. Zool. 73:1495-1502;1995.

4. Dubois, M.; Gilles, K.A.; Hamilton, J.K.; Reber, P.A.; Smith, F. Colorimetric method for determination of sugar and related substance. Anal. Chem. 28:350-356;1956.

5. Fenaux, L.; Malara, G.; Cellario, C.; Charra, R.; Palazzoli, I. Evolution des constituants hiochimiques des principaux compartiments de l'oursin Arbacia lixula (L.) au cours d'un cycle sexuel et des effets d'un jeûne de courte durée au cours de la maturation sexuelle. J. Exp. Mar. Biol. Ecol. 28:17-30;1977.

6. Fenaux, L.; Malara, G.; Charra, R. Effect d'un jeune de courte durée sur les principaux constituants biochimiques de l'oursin Arbacin lixula. I. Stade de repos sexuel. Mar. Biol. 30:239-744; 1975.

7. Fernandez, C. Recherches préliminaires à la mise en place d'un pilote d'aquaculture de l'oursin Paracentrotus liqidus dans un étang corse. Mém. D.E.A. Océanologie, Univ. Aix-Marseille II; 1990 .

8. Fernandez, C. Croissance et nutrition de Paracentrotus litidus dans le cadre d'un projet aquacole avec alimentation artificielle. These University Corse; 1996.

9. Fernandez, C.; Caltagirone, A. Growth rate of adult Paracentrotus lividus in a lagoon environment: The effect of different diet types. In: David, B.; Guille, A., Féral, J.P.; Roux, M. (eds). Echinoderms through Time. Rotterdam: A.A. Ralkema; 1994: $655-660$.

10. Fernandez, C.; Dombrowski, E.; Caltagirone, A. Gonadic growth of adult sea urchin Paracentrotus lividus (Echinodermata: Echinoidea) in rearing: The effect of different diet type. In: Emson, R.; Smith, A.; Camphell, A. (eds). Echinoderms Research 1995. Rotterdam: A.A. Balkema; 1995:269 275.

11. Giese, A.C. On the biochemical constitution of some Echinoderms. In: Boolotian, R.A. (ed). Physiology of Echinodermata. New York: John Wiley; 1966:757-796.

12. Giese, A.C. Lipids in the economy of marine invertebrate Physiol. Rev. 46:244-298;1966.

13. Gonor, J.J. Reproductive cycles in Oregon populations of the echinod Strongylocentrotus purpuratus (Stimpson). Annual 
gonad growth and ovarian gametogenic cycles. J. Exp. Mar. Biol. Ecol. 12:5-64;1973.

14. Grosjean, $P_{. ;}$Jangoux, M. Effect light on feeding in cultivated echinoids (Paracentrotus lividus). In: David, B.; Guille, A.; Féral, J.P.; Roux, M., (eds). Echinoderms through Time. Rotterdam: A.A. Balkema; 1994:691.

15. Klinger, T.S.; Watts, S.A.; Forcucei, D. Effect on short term feeding and starvation on storage and synthetic capacities of gut tissues of Lytechinus variegatus (Lamarck) (Echinodermata: Echinoidea). J. Expl. Mar. Biol. Ecol. 117:187-195;1988.

16. Lares, M.T.; McClintock, J.B. The effect of food quality and temperature on the nutrition of the carnivorous sea urchin Eucidaris tribuloides (Lamarck). J. Exp. Mar. Biol. Ecol. 149: $279-286 ; 1991$.

17. Lawrence, J.M. Lipids reserves in the gut of three species of tropical sea urchins. Carib. J. Sci. 7(1-2):65-68;1967.

18. Lawrence, J.M. The effect of starvation on the lipid and carbohydrate levels of the gut of the tropical sea urchin Echinometra mathaei (Blainville). Pacif. Sci. 24:487-489;1970.

19. Lawrence, J.M. Effect of starvation on the organic nutrient reserves in the test of Tripneustes gratilla (L.) (Echinodermata: Echinoidea) from the gulf of Elat. Israel J. Zool. 20:249-251: 1971.

20. Lawrence, J.M.; Byrne, M. Allocation of resources to body components in Heliocidaris erythrogramma and Heliocidaris tuberculata (Echinodermata: Echinoidea). Zool. Sci. Jpn. 11:33$137 ; 1994$.

21. Lawrence, J.M.; Guille, A. Organic composition of tropical, polar and temperate-water echinoderms. Comp. Biochem. Physiol. 72B:283-287;1982.

22. Lawrence, J.M.; Kafri, J. Number biomass, and caloric content of the echinoderm fauna of the rocky shores of Barbados. Mar. Biol. 52:87-91;1979.

23. Lawrence, J.M.; Lane, J.M. The utilisation of nutrients by post metamorphic echinoderms. In: Jangoux, M.; Lawrence, J.M. (eds). Echinoderm nutrition. Rotterdam: A.A. Balkema; 1982:331-371.

24. Lawrence, J.M.; Lawrence, A.L.; Giese, A.C. Role of the gut as a nutrient-storage organ in the purple sea-urchin (Strongylocentrotus purpuratus). Physiol. Zool. 39:281-290;1966.

25. Le Gall, P.; Bucaille, D. Intérêt d'un élevage intensif de l'oursin violet Paracentrotus lividus. In: Boudoursque C. F. (ed).
Colloque international sur Paracentrotus lividus et les oursins comestibles. Marseille: GIS Posidonie; 1987:399-405.

26. Le Gall, P.; Bucaille, D.; Grassin, J.B. Influence de la température sur la croissance de deux oursins comestibles, Paracentrotus lividus et Psammechinus miliaris. In: De Ridder, C.; Dubois, P.; Lahaye, Jangoux, M. (eds). Echinoderm Research. Rotterdam: A.A. Balkema; 1990:183-188.

27. Lowry, O.H.; Rosebrough, N.J.; Farr, A.L.; Randall, R.J. Protein measurement with folin reagent. J. Biol. Chem. 193:265$275 ; 1951$.

28. Magniez, P. Reproductive cycle of the brooding echinoid Abatus cordatus (Echinodermata) in kerguelen (Antartic Ocean): Changes in the organ indices, biochemical composition and caloric content of the gonad. Mar. Biol. 74:55-64;1983.

29. McClintock, J.B.; Cameron, J.L.; Young, C.M. Biochemical and energetic composition of bathyal echinoids and an asteroid, holothuroid and crinoid from the Bahamas. Mar. Biol. 105:175-183;1990.

30. McClintock, J.B.; Pearse, J.S. Biochemical composition of antartic echinoderms. Comp. Biochem. Physiol. 86B:683-687; 1987.

31. McClintock, J.B.; Hopkins, T.: Watts, S.A.; Marion, K. The biochemical composition of somatic body components of echinoderms from the northern gulf of Mexico. Comp. Biochem. Physiol. 95A:529-532;1990.

32. Miwa, K. Biochemical studies on sea urchin. 1- Variation of nutrient stocks in sea urchin gonad processing the maturity. Bull. Hokkaido Reg. Fish. Res. Lab. 31:73-88;1966.

33. Moss, J.E.; Lawrence, J.M. Changes in carbohydrates, lipids and proteins levels with age and season in the sand dollar $\mathrm{Mel}$ lita quinquiesperforata. J. Exp. Mar. Biol. Ecol. 8:225-239;1972.

34. Traer, K. The consumption of Posidonia oceanica Delile by echinoids at the isle of Ischia, In: Jangoux, M. (ed). Echinoderm: Present and past. Rotterdam: A.A. Balkema; 1980:241244.

35. Verlaque, M. Relations entre Paracentrotus lividus (Lmk.) et le phytobenthos de Méditerrané occidentale. In: Boudouresque, C. F. (ed). Colloque international sur Paracentrotus lividus et les oursins comestibles. Marseille: Gis Posidonie; 1987:5-36.

36. Zar, J. H. Biostatistical Analysis, 2nd Edition. New York: Prentice Hall International; 1984. 